\title{
Enhanced induction of HIV-specific CTL by dendritic cell-targeted delivery of SOCS-1 siRNA
}

\author{
Sandesh Subramanya ${ }^{1,2^{*}}$, Chunting Ye ${ }^{1,2}$, Sang-Soo Kim ${ }^{1,2}$, Premalata Shankar ${ }^{1,2}$ \\ From $16^{\text {th }}$ International Symposium on HIV and Emerging Infectious Diseases \\ Marseille, France. 24-26 March 2010
}

\section{Background}

Dendritic cells (DC) are potent antigen-presenting cells that play a critical role in the activation of $\mathrm{T}$ cells. Antigen-loaded dendritic cell-based vaccines have been used for immunotherapy of human cancers and chronic infections, but only with limited success. RNAi-mediated silencing of negative immunoregulatory molecules expressed by DCs may provide a strategy to enhance the potency of DC-based vaccines and immunotherapy.

\section{Methods}

We have used a novel human HLA-A2 transgenic NOD/SCID-iL2rg chain -/- mice reconstituted with CD34+ HSC from A2 donors as a preclinical model to induce a robust CD8 $+\mathrm{T}$ cell-mediated protective immune response to HIV infection.

\section{Results}

SOCS-1 knockdown in human DCs a) enhanced their cytokine responses to LPS, and stimulated a strong mixed lymphocyte reaction in vitro, b) elicited a strong primary in vitro response to HLA-A2-restricted Melan-A/MART-1 and HIV Gag epitopes in naïve CD8+ T cells from healthy donors and c) increased the HIV gag-specific proliferation and polyfunctional cytokine response in CD8 $\mathrm{T}$ cells from seropositive subjects. More importantly, injection of gag peptide-pulsed, SOCS-1 silenced, but not just peptide pulsed HLA-A2 DCs, in the novel HLA-A2 humanized mice, gave rise to a robust multi-epitope-HIV specific $\mathrm{CD} 8 \mathrm{~T}$ cells that could dramatically reduce the replication of a HIV-Gag-vaccinia recombinant challenge virus infection.

\section{Discussion}

These results demonstrate the feasibility of using manipulated DC as a prophylactic vaccine strategy for HIV infection in a humanized mouse model.

\section{Author details}

${ }^{1}$ TTUHSC, El Paso, USA. ${ }^{2}$ Harvard Medical School, Boston, USA.

Published: 11 May 2010

doi:10.1186/1742-4690-7-S1-P12

Cite this article as: Subramanya et al:: Enhanced induction of HIVspecific CTL by dendritic cell-targeted delivery of SOCS-1 siRNA.

Retrovirology 2010 7(Suppl 1):P12.

\footnotetext{
* Correspondence: sandesh.subramanya@ttuhsc.edu
}

${ }^{1}$ TTUHSC, El Paso, USA

Submit your next manuscript to BioMed Central and take full advantage of:

- Convenient online submission

- Thorough peer review

- No space constraints or color figure charges

- Immediate publication on acceptance

- Inclusion in PubMed, CAS, Scopus and Google Scholar

- Research which is freely available for redistribution

Submit your manuscript at www.biomedcentral.com/submit
C Biomed Central 